\title{
NANCY NATURAL RADIOCARBON MEASUREMENTS IV
}

\author{
P RICHARD, B GUILLET*, R JAEGY and R COPPENS \\ Centre de Recherches Radiogéologiques \\ Nancy-Vandoeuvre BP 452, 54000 NANCY, France
}

This list includes results of measurements made during 1973-1974 and 1975 in the Natural Radiocarbon Laboratory of the Centre de Recherches Radiogéologiques de Nancy (CRR).

Laboratory procedures and techniques are the same as reported in Hassko et al (1974) where the sample is synthesized to benzene and counted for 24 hours. Radiocarbon ages are calculated using ${ }^{14} \mathrm{C}$ half-life of 5568 years; $95 \%$ activity of NBS oxalic acid is used as the modern standard. The counting errors are expressed at $1 \sigma$ confidence level. ADIBC* dates are corrected according to the MASCA correction curve.

\section{SAMPLE DESCRIPTIONS}

\section{ARCHAEOLOGIC AND HISTORIC SAMPLES}

\section{A. Peru}

\section{Chilca program series}

Samples are from different prehistoric villages, in Chilca basin, central coast of Peru. Coll by Frederic Engel, Dir Mission archeol française au Pérou and Inst Antropol y agric Precolombina, Univ Nac Agraria, Lima, Peru.

Samples were dated to a) establish prehistoric population maps, b) contribute to the establishment of climatic curves particularly by dating the appearance of diagnostic elements, c) differentiate the pre-agricultural from Neolithic populations, and d) date prototypical villages of different periods.

\section{Pre-agricultural sites}

\section{Ny-231. Chilca, V 3230}

$5630 \pm 70$

Wood charcoal from prehistoric village, Loma Huarangal, 12 b-VII 9160, Level 200, alt $350 \mathrm{~m}\left(12^{\circ} 25^{\prime} 30^{\prime \prime} \mathrm{S}, 76^{\circ} 39^{\prime} 35^{\prime \prime} \mathrm{W}\right)$. Comment (FE): because of presence of Mesodesmas with tegument, village seems to belong to Pre-agricultural period. Estimated age: 10,000 to 5500 вP. Coll 1973 by F Engel and B Ojeda.

\section{Ny-356. Chilca, V 2850}

$3460 \pm 70$

Shells assoc with detritus stuck to floor of hut from prehistoric village

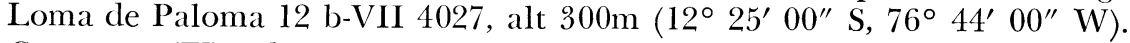
Comment $(\mathrm{FE})$ : dates appearance of stone wall on central coast of Peru. Estimated age: 6500 вр. Coll 1973 by F Engel.

* Centre de Pédologie Biologique, Nancy-Vandoeuvre. 


\section{Ny-242. Chilea, V 3247}

$6030 \pm 180$

$4990 \mathrm{BC}^{*}$

Vegetal material and fiber mat fragments surrounding a corpse buried in detritus covering the huts of village of late Pre-agricultural period, from Village 12 b-VII 613, Loma de Paloma, Tomb 12, Level 400, alt $250 \mathrm{~m}\left(12^{\circ} 25^{\prime} 50^{\prime \prime} \mathrm{S}, 75^{\circ} 45^{\prime} 00^{\prime \prime} \mathrm{W}\right)$. Comment (FE): dates of 2nd village of 3 superimposed villages at this site. Estimated age: 6000 to 6500 BP. Coll 1973 by F Engel and B Ojeda.

\section{Ny-243. Chilca, V 3248}

$6510 \pm 180$

Vegetal material and fragments of small cord surrounding a corpse from village Loma de Paloma 12 b-VII 613, Level 500, alt 250m, Tomb 11, dug from deepest bed of detritus downward, village of late Pre-agricultural $\left(12^{\circ} 25^{\prime} 00^{\prime \prime} \mathrm{S}, 76^{\circ} 45^{\prime} 00^{\prime \prime} \mathrm{W}\right)$. Comment $(\mathrm{FE})$ : dates 3rd and oldest of 3 superimposed villages at this site. Coll 1973 by F Engel and B Ojeda. Estimated age: 6000 to $6500 \mathrm{BP}$.

2. Sites of Neolithic III or Preceramic

\section{Ny-224. Chilca, V 2832}

$4070 \pm 90$

2690-2800 ВС*

Shells from village Loma de Los Cardos (Jaboncillo), 12 b-VII 6501, Level $100\left(12^{\circ} 30^{\prime} 31^{\prime \prime} \mathrm{S}, 76^{\circ} 38^{\prime} 39^{\prime \prime} \mathrm{W}\right)$. Comment $(\mathrm{FE})$ : sample gathered from interior of detritus covering vestiges of huts. By appearance, it does not seem to be related to Pre-agricultural, but to beginning of Neolithic II or late Pre-maize. Date establishes relation to Pre-agricultural or Neolithic I village. Preceramic with haricot and cotton. Estimated age: 4500 to 4000 вP. Coll 1973 by F. Engel.

\section{Ny-230. Chilca, V 2829}

$4120 \pm 80$

2850 в * $^{*}$

Wood charcoal from village Loma de Los Cardos, 12 b-VII 6510, alt $500 \mathrm{~m}\left(12^{\circ} 33^{\prime} 00^{\prime \prime} \mathrm{S}, 76^{\circ} 37^{\prime} 38^{\prime \prime} \mathrm{W}\right)$. Comment (FE): see Ny-224. Coll 1973 by F. Engel.

3. Sites with ceramics of Neolithic $I V, V$ and beginning of Chalcolithic

Ny-227. Chilca, V 3232

$3340 \pm 80$

1690-1710 BC*

Shells from village Loma de Huarangal 12 b-VII 8570, Level 100, alt $375 \mathrm{~m}\left(12^{\circ} 30^{\prime} 30^{\prime \prime} \mathrm{S}, 76^{\circ} 39^{\prime} 40^{\prime \prime} \mathrm{W}\right)$. Comment $(\mathrm{FE})$ : sample gathered from interior of bed of detritus covering ruins of stony small houses. Dates appearance of maize and ceramics in lower central Andes. Estimated age: 3500 to 3300 BP. Coll 1973 by F Engel and B Ojeda.

\section{Ny-229. Chilca, V 2828}

$2530 \pm 60$

790 BC$^{*}$

Shells from village Loma de Camotillo 12 b-VII 945, Level 1, alt $675 \mathrm{~m}\left(12^{\circ} 30^{\prime} 31^{\prime \prime} \mathrm{S}, 76^{\circ} 39^{\prime} 40^{\prime \prime} \mathrm{W}\right)$. Comment (FE): gathered material from layer within embankment of a culture terrace. Dates ceramics and 
architecture of village. Ceramic seems to belong to Chavin society. Estimated age: 2800 to 2500 вP. Coll 1973 by F Engel.

\section{Ny-228. Chilea, V 2809}

$$
2130 \pm 70
$$

Shells from village Loma de Paloma 12 b-VII 6048, Level 400, alt $250 \mathrm{~m}\left(12^{\circ} 25^{\prime} 45^{\prime \prime} \mathrm{S}, 76^{\circ} 44^{\prime} 40^{\prime \prime} \mathrm{W}\right)$. Comment (FE): shells gathered from interior of pile of ash and detritus covering house walls, silos and well. Dates pre-Columbian well assoc to Lapa Lapa ceramic produced from 2200 to 1800 BC. Coll 1969 by F Engel.

\section{Chillon program series}

\section{Pre-agricultural sites}

\section{Ny-235. Montaro basin, V 3272}

Wood charcoal from prehistoric grotto Yanamachay 10 c-XII 1, Level 600 , alt $4.40 \mathrm{~m}\left(11^{\circ} 03^{\prime} 00^{\prime \prime} \mathrm{S}, 76^{\circ} 21^{\prime} 20^{\prime \prime} \mathrm{W}\right)$. Comment (FE): 6th, last and deepest bed found during stratigraphic excavation, typical of groups before altithermal, dates lithic material. Estimated age: $<7500$ вP. Coll 1973 by F Engel and B Ojeda.

\section{Ny-237. Montaro basin, V 3276} 等 to last bed and oldest found during stratigraphic excavation. Age seems to be late Pre-agricultural of Paloma type. Dates human occupation. Coll 1973 by F Engel and B Ojeda.

\section{Sites with ceramics of Neolithic IV or $V$}

\section{Ny-234. Montaro basin, V 3269}

$3420 \pm 60$

Wood charcoal from village Curuqaqa, 10 c-IX 4, Level 100, alt $4.24 \mathrm{~m}\left(10^{\circ} 55^{\prime} 20^{\prime \prime} \mathrm{S}, 76^{\circ} 20^{\prime} 15^{\prime \prime} \mathrm{W}\right)$. Comment (FE): 1st bed with detritus found under sediments of recent surface. Dates occupation of grotto with walls ornamented with painting. Estimated age: 3500 to $3000 \mathrm{BP}$. Coll by F Engel and B Ojeda.

\section{Ny-233. Montaro basin, V 3268}

$$
3260 \pm 60
$$

Wood charcoal from vilage Cajocancha $1,10 \mathrm{c}$ $4.60 \mathrm{~m}\left(11^{\circ} 04^{\prime} 37^{\prime \prime} \mathrm{S}, 76^{\circ} 23^{\prime} 08^{\prime \prime} \mathrm{W}\right)$. Comment: period of village. Estimate age: 3500 to 3000 BP. Coll by F Engel and B Ojeda.

\section{Ny-358. Southern deserts program, V 3549}

$$
870 \pm 80
$$

Fragments of reed from mouth of Rio Ica (Eneolithic sites) Village, 15 b-VII 40, Level 200, alt $20 \mathrm{~m}\left(14^{\circ} 52^{\prime} 00^{\prime \prime} \mathrm{S}\right.$, $\left.75^{\circ} 33^{\prime} 34^{\prime \prime} \mathrm{W}\right)$. Comment $(\mathrm{FE})$ : sample from within sand cover of beach eolian sediments. Dates 
raft $7 \mathrm{~m}$ long with balancing-pole decorated with multicolored cotton amulets and with "spondyles", the only presently known pre-Columbian raft. Estimated age: 700 to 500 BP. Coll 1974 by F Engel.

\section{Bandurria Huahco series}

Wood charcoal from Km 127 of Panamericana main rd. Coll 1973 by Rosa Fung, Univ Nac Major San Marcos, Lima, Peru. Dated to determine age of site containing feminine statuettes of unfired clay. Agriculture without maize was already established.

\section{Ny-244. Bandurria, V 3277}

$4480 \pm 70$

Sample from Lado (E), Level 4. Estimated age: 5500 to 3500 вр.

Ny-245. Bandurria, V 3278

$4320 \pm 90$

Sample from Lado opuesto (W) Level 3. Estimated age: 5500 to $3500 \mathrm{BP}$

Ny-246. Bandurria, V 3279

$4530 \pm 80$

Sample from Hallazgo 18.

3350 в $^{*}$

B. France

Ny-223. Nany

AD 1410

$490 \pm 60$

Trunk of oak tree, old water pipe. Depth $4.50 \mathrm{~m}\left(48^{\circ} 41^{\prime} 34^{\prime \prime} \mathrm{N}, 6^{\circ}\right.$ 11' 17" E). Coll by J Florentin and R Jaegy, ENSG, Nancy.

Ny-336. Avioth

$870 \pm 80$

Fragment of linden tree from statue ND Avioth, Meuse. Comment: agrees with assumed antiquity of this renewed statue for pilgrimage of Avioth. Coll by cure d'Avioth, 55, Montmedy.

Ny-354. Arnaville

$\mathbf{3 1 0} \pm 50$

Fragment of oak from ancient water mill. Coll by $\mathrm{R}$ Jacques, Arnaville_-Pagny/Moselle.

Ny-353. Joinville

$1580 \pm 80$

Human bones. Coll by Martin Fac Pharmacie, Nancy.

$$
\text { C. Africa }
$$

Ny-357. Ifan

$1980 \pm 60$

AD 20

Carbonized wood fragments and charcoal near Megalithic monument (Cromlech), Tikene Boussoura, arr Kounpentoum, depth $1.05 \mathrm{~m}$. Coll by Ifan, Dakar. 
II. HYDROGEOLOGIC SAMPLES

Carbonates extracted from fossil water from Tarabulus dist, Libyan Arab Republic. Coll by GEFLI and GERSAR Soc, Nîmes, France.

\section{Ny-214. Chameau mort aquifer \\ $15,380 \pm 440$}

Sample from well drilled in Jurassic at Jawsh $\left(31^{\circ} 57^{\prime} \mathrm{N}, 11^{\circ} 43^{\prime} \mathrm{E}\right)$. Depth of sampled aquifer from 110 to $140 \mathrm{~m}$.

Ny-208. Jawsh Takbal aquifer

$18,600 \pm 30$

Sample from well drilled in middle Jurasic at Tiji $\left(32^{\circ} 56^{\prime} \mathrm{N}, 11^{\circ}\right.$ $\left.23^{\prime} \mathrm{E}\right)$. Depth of sampled aquifer from 62 to $70 \mathrm{~m}$.

Gefara and coastal belt first aquifer series

$\begin{array}{ll}\text { Ny-205. Zawiyah drilling } & \mathbf{4 4 0 0} \pm 90\end{array}$

From Quaternary deposit, Az Zawiyah $\left(32^{\circ} 48^{\prime} \mathrm{N}, 12^{\circ} 41^{\prime} \mathrm{E}\right)$. Depth of sampled aquifer, $64 \mathrm{~m}$.

Ny-201. BP 1/21

$21,740 \pm 440$ $130 \mathrm{~m}$.

From Triasic, Wadi al Hiram $\left(32^{\circ} 23^{\prime} \mathrm{N}, 13^{\circ} 05^{\prime} \mathrm{E}\right)$. Depth of aquifer

Ny-213. T3

$23,400 \pm 240$

From Triassic, SW al Aziziyah $\left(32^{\circ} 18^{\prime} \mathrm{N}, 11^{\circ} 53^{\prime} \mathrm{E}\right)$. Depth of aquifer 92 to $174 \mathrm{~m}$.

Ny-211. T 11

$17,570 \pm 250$

From Triassic, S al Aziziyah $\left(32^{\circ} 21^{\prime} \mathrm{N}, 13^{\circ} 02^{\prime} \mathrm{E}\right)$. Depth of aquifer 136 to $155 \mathrm{~m}$.

Gefara and coastal belt deep aquifer series

Ny-206. DW Nasiria $\quad 15,820 \pm 350$

From Miocene, NW Aziziyah $\left(32^{\circ} 38^{\prime} \mathrm{N}, 12^{\circ} 47^{\prime} \mathrm{E}\right)$. Depth of aquifer from 265 to $310 \mathrm{~m}$.

Ny-209. T 10

$18,780 \pm 270$

From Miocene, Bin Gashir $\left(32^{\circ} 40^{\prime} \mathrm{N}, 13^{\circ} 17^{\prime} \mathrm{E}\right)$. Depth of aquifer 486 to $546 \mathrm{~m}$.

\section{Ny-207. T 2}

$19,330 \stackrel{1450}{-1230}$

From Miocene, S az Aziziyah $\left(32^{\circ} 37^{\prime} \mathrm{N}, 12^{\circ} 41^{\prime} \mathrm{E}\right)$. Depth of aquifer 371 to $391 \mathrm{~m}$.

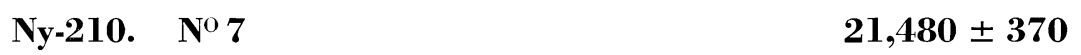

From Cretaceous, Sidi Mesri $\left(32^{\circ} 52^{\prime} \mathrm{N}, 13^{\circ} 12^{\prime} \mathrm{E}\right)$. Depth of aquifer from 445 to $450 \mathrm{~m}$.

\section{Ny-203. T 4}

$$
15,230 \begin{aligned}
& \pm \mathbf{4 7 0} \\
& -\mathbf{5 4 0}
\end{aligned}
$$

From Cretaceous, S Zliten $\left(32^{\circ} 20^{\prime} \mathrm{N}, 14^{\circ} 35^{\prime} \mathrm{E}\right)$. Depth of aquifer from 235 to $265 \mathrm{~m}$. 
Ny-238. DW 7

$12,770 \pm \pm 180$

From Cretaceous, Wadi ar Ramil $\left(32^{\circ} 36^{\prime} \mathrm{N}, 13^{\circ} 35^{\prime} \mathrm{E}\right)$. Depth of aquifer from 200 to $300 \mathrm{~m}$.

General Comment: only one "young" age ( $\mathrm{Ny}-205)$ was encountered. Although for last $3000 \mathrm{yr}$, climatic conditions of Sahara have remained relatively similar to those prevailing today, it is known from botanical research that a major pluvial period occurred between 3000 and 7000 yr ago. All other samples have apparent ages between 12,000 and 24,000 yr (Ny-201, 202, 206-214) samples between 17,000 and 22,000 yr clearly predominant. This category can be linked to paleoclimatologic events relatively well known on North-African scale.

\section{REFERENCE}

Hassko, B, Guillet, B, Jaegy, R, and Coppens, R, 1974, Nancy natural radiocarbon measurements III : Radiocarbon, v 16, p 118-130. 